NBER WORKING PAPER SERIES

\title{
CAPITAL FLOWS AND EXCHANGE RATE VOLATILITY: SINGAPORE'S EXPERIENCE
}

\author{
Basant K. Kapur \\ Working Paper 11369 \\ http://www.nber.org/papers/w11369 \\ NATIONAL BUREAU OF ECONOMIC RESEARCH \\ 1050 Massachusetts Avenue \\ Cambridge, MA 02138
}

May 2005

A previous version of this paper was presented at the NBER's International Capital Flows Conference, Santa
Barbara, CA, Dec. 16-18 2004. I wish to thank Sebastian Edwards, Martin Feldstein, Anusha Chari (the
discussant), and other participants for their most helpful comments. The usual disclaimer applies. The views
expressed herein are those of the author(s) and do not necessarily reflect the views of the National Bureau
of Economic Research.

(C2005 by Basant K. Kapur. All rights reserved. Short sections of text, not to exceed two paragraphs, may be quoted without explicit permission provided that full credit, including $\odot$ notice, is given to the source. 
Capital Flows and Exchange Rate Volatility: Singapore's Experience

Basant K. Kapur

NBER Working Paper No. 11369

May 2005

JEL No. F4, F3

\begin{abstract}
Singapore's experience with international capital flows over the past two decades or so has been a rather - although not completely - benign one, owing to strong fundamentals and generally wellconceived macro-economic policies. We begin by briefly discussing the experience in 1998 of Hong Kong, another city-state with a well-developed banking system and equities market, and operating on a Currency Board (CB) system (although with some differences from Singapore's CB system). The discussion serves to identify some 'areas of vulnerability' in the Hong Kong set-up at that time. We next discuss Singapore's policy background and early experience, and in the light of Hong Kong's experience are better able to appreciate how Singapore's policy framework served to circumvent or minimize important vulnerabilities. Particular attention is paid to Singapore's exchange-rate policy and its policy of non-internationalization of the Singapore dollar. Equity- and currency- market interactions are also considered. We next show how Singapore emerged relatively unscathed from the 1997 Asian Crisis. Lastly, we discuss Singapore's debt markets, and show how under the imperative of promoting the development of its bond markets the non-internationalization policy has been progressively relaxed, while retaining key safeguards.

Basant K. Kapur

Department of Economics

National University of Singapore

Kent Ridge

S (117570) Singapore

ecskapur@nus.edu.sg
\end{abstract}




\section{Introduction}

Singapore's experience with international capital flows over the past two decades or so has been a rather - although not completely - benign one, owing to strong fundamentals and generally well-conceived macro-economic policies. At the same time, useful lessons can be learnt, regarding issues such as exchange rate policy, the policy of non-internationalization of the Singapore dollar, and unavoidable fallout effects of capital flow volatility even in generally sound environments and how these may best be dealt with.

A feature of Singapore's economy that sets it apart from various of the other countries discussed in this Conference is its well-developed banking system and equities market, and the fact that it is on a - modified - currency board (CB) system. Its bond market is, however, less developed, although in recent years as discussed below measures have been taken to foster its growth. It may be useful, therefore, to begin by comparing Singapore's experience with that of another state with a well-developed financial system, namely Hong Kong: the latter, in addition, operates what may be termed a 'pure' CB system. Notwithstanding the economic similarities, Singapore and Hong Kong have had rather different experiences with capital flows, and an examination of why this has been so turns out to be rather instructive. In Section II, therefore, we briefly examine Hong Kong's experience during the Asian Crisis of 1997-98, and identify its 'areas of vulnerability'. In Section III, we discuss Singapore's policy background and how it responded to a significant speculative attack in 1985, and draw lessons from this. Further lessons are drawn in Section IV, when we consider Singapore's experience during the Asian Crisis of 1997-98. Section V discusses Singapore's debt markets, an interesting feature being that both Singapore and Hong Kong have in recent years encouraged foreign enterprises to float bond issues in $\mathrm{S} \$$ and $\mathrm{HK} \$$ respectively, and Section VI concludes. An Annex provides a chronology of the evolution of capital controls (specifically, the evolution of the non-internationalization policy) in Singapore. 


\section{Hong Kong - the 1997-98 experience}

As indicated above, our discussion here will be fairly brief, given that our main focus is on Singapore, and is designed primarily to provide a comparative perspective on Singapore's experience. ${ }^{1}$ A minimalist definition of a pure CB system is that it is one in which (a) domestic currency is issued or redeemed only in exchange for foreign currency, and (b) at a fixed exchange rate, usually vis-a-vis a single foreign currency, termed the reserve currency. A modified CB system, discussed further below, is then one in which (a) holds, but not (b). A pure system aptly describes the Hong Kong situation, with the exchange rate fixed at HK\$7.8:US\$1 since October 1983. Moreover, the monetary base in Hong Kong was rather small, given that it does not impose reserve requirements on banks and has an efficient, real-time interbank payment system so that 'the aggregate balance that banks maintain in their clearing accounts held with the currency board' (Yam 1998b) is low. This rendered Hong Kong vulnerable to speculative capital outflows, of which there were a number in mid-1997 through mid-1998: these did not succeed, in part because the resulting high interest rates adversely affected the speculators too, who had borrowed Hong Kong dollars in the interbank market to launch their attacks. The high interest rates (the overnight interest rate actually rose to $280 \%$ on October 23 1997) and their adverse effects on the stock market and economic activity in general were however a source of concern. ${ }^{2}$

The really major attack, however, occurred in August 1998, and Yam (1998b) describes the so-called 'double-play' thus:

'In August [after an announcement that 'first-quarter GDP growth had been negative'] the speculators adopted a more sophisticated ploy. They introduced a

\footnotetext{
${ }^{1}$ We draw here mainly on Rzepkowski (2000), Yam (1998 a, b), and Corsetti, Pesenti, and Roubini (2001).

2 The attacks reflected contagion from crises elsewhere in the region (Rzepkowski, Hashimoto and Ito (2004)), and uncertainties associated with Hong Kong's accession to China. While Yam (1998b) refers to the interest rate increases as an 'autopilot mechanism' - an inevitable concomitant of the CB system - Rzepkowski contends ( $p$. 15) that they were partly induced, on occasions, by discretionary increases in the Hong Kong Monetary Authority’s (HKMA’s) discount rate.
} 
form of double play aimed at playing off the currency board system against the stock and futures markets. First, to avoid being squeezed by high interest rates, they prefunded themselves in Hong Kong dollars in the debt market, swapping US dollars for Hong Kong dollars with multilateral institutions that have raised Hong Kong dollars through the issue of debt. At the same time, they accumulated large short positions in the stock index futures market. They then sought to engineer extreme conditions in the money market by dumping huge amounts of Hong Kong dollars. This sell-off was intended to cause [either a devaluation or] a sharp interest rate hike, which in turn would have sent the stock market plummeting. The collapse of the stock market would have enabled them to reap a handsome profit from the futures contracts they had taken out.'

Presumably, a double play facilitates a stronger currency attack, since the higher interest cost resulting from an attack of a given size is at least partly offset by the possible gains from short-selling in the stock index futures market. Rzepkowski points out ( $p .17)$ that speculators also engaged in short-selling of stocks, and that 'the hedge funds involved in the speculation were identified as being the Quantum Fund of George Soros, the Tiger Fund, the Moore Global Investment, and the Long Term Capital Management'. Their prefunding activities had driven the Hong Kong interest rate premium over the US dollar to about 5 percentage points (Yam, 1998a). It was estimated (Yam, 1998b) that 'the hedge funds involved had amassed in excess of HK\$30 billion in currency borrowings, at an interest cost of around HK\$4 million a day. They also held an estimated 80,000 short contracts, which translated into the following calculation: for every fall of 1,000 points in the Hang Seng index they stood to make a profit of HK $\$ 4$ billion.' Owing to the marking-to-market of their margin accounts with the Futures Exchange, they stood to gain daily from incremental falls in the Hang Seng index (Rzepkowski, pp. 17-8).

In the event, the attack proved unsuccessful. Like Singapore, Hong Kong has very substantial nonmonetary foreign reserves - reserves in excess of that required to back the monetary base. At the time, it was unexpectedly confronted with a fiscal deficit, and had to convert part of these reserves into Hong Kong dollars to meet its fiscal obligations. 
'The immediate impact of this sale [of foreign currency], of an amount exceeding the HK $\$ 30$ billion accumulated by the hedge funds, was the non-trigger of high interest rate' (Rzepkowski, $p$. 19). In addition, and quite unconventionally, 'between the $14^{\text {th }}$ and $28^{\text {th }}$ August 1998, the HKMA intervened via the Exchange Fund on the stock and futures markets. It acquired a portfolio of equities and HSI futures for an amount of about US\$15 billion, that is $7 \%$ of the capitalization and around $30 \%$ of the current [1998] Hang Seng Index value...About 13\% of its nonmonetary reserves..were allocated to these interventions, inducing an important injection of liquidity into the money market' (ibid.). By November, the portfolio had risen to US\$19 billion in value, and during the interim speculators 'were forced to close out their short positions, in many cases with heavy losses' (Yam, 1998b). The portfolio was subsequently placed under the management of a separate company at arms-length from the HKMA, with the aim of divesting it gradually.

After August 1998, systemic improvements were introduced, with the intention of minimizing the occurrence of future attacks. The Exchange Fund, which manages Hong Kong's monetary and nonmonetary reserves had since 1990 issued bills to promote the development of the local bond market, and in September 1998 virtually unrestricted discounting of Exchange Fund bills by commercial banks at the discount window of the HKMA, at non-penal rates, was introduced. Effectively, this almost doubled the size of the monetary base, and serves to significantly reduce the interest rate response to a capital outflow of a given magnitude (Rzepkowski, $p p$. 18-20). In addition, the government has 'brought in a 30-Point package tightening the regulation of the securities and future markets. Measures in the package include the strict enforcement of the $\mathrm{T}+2$ settlement process, imposing a super margin on brokers with highly concentrated positions, introducing the client identity rule, increasing the penalty for naked short selling, creating a new offence for unreported short sales, and introducing new requirements for stock lenders to keep proper records of their lending activities. In parallel, SEHK re-introduced the up-tick rule (no short selling below the current best ask price) for covered short selling and HKFE tightened the large open position reporting requirements and imposed 
position limits for HSI 33 Futures and Option Contracts' (Dickens (2002), p. $3^{3}$ ). Subsequently, 'relaxation measures applicable to certain market neutral transactions have been introduced' (ibid.).

While the Hong Kong authorities have taken the view that the hedge funds were engaged in predatory market manipulation, Corsetti et. al. adopt a more agnostic position: 'the hypothesis of rational investors taking short positions in two markets (based on an assessment of economic fundamentals) and the hypothesis of a double play (suggesting market manipulation) are observationally equivalent' ( $p .44)$. One could hypothesize, alternatively, that the weakening fundamentals, due to both domestic and regional developments, had 'pushed' the economy into a zone in which multiple equilibria (discussed further below) existed. Speculators then endeavoured to drive the economy to the unfavourable equilibrium (possibly by hoping that their actions would serve as a signal to others), seeking to reap large profits in the process, and were not averse to resorting to questionable means (such as naked short selling) to do so. One would then interpret the HKMA's actions as seeking to maintain the economy at the favourable equilibrium - successfully, as it turned out. In this framework, the equilibria themselves - in particular the equilibrium level of stock prices - depend inter alia on the extent of policy intervention by the authorities. ${ }^{4}$

\footnotetext{
${ }^{3}$ Prior to launching their attack in August, the hedge funds had borrowed Hong Kong stocks, to a large extent in the more efficient offshore market, from international fund managers and custodians (Rzepkowski, fn. 20), and in addition, owing to 'lax settlement requirements' (Yam, 1998a, quoted in Rzepkowski, fn. 22) naked short selling was also practiced, even though it was against the law. Corsetti et. al. also quote ( $p$. 43) a study by the Financial Stability Forum (2000): 'Aggressive trading practices by HLIs (highly leveraged institutions) reportedly included concentrated selling intended to move market prices, large sales in illiquid offshore trading hours, and "spoofing" of the electronic brokering services to give the impression that the exchange rate had moved beyond the HKMA's intervention level. There were frequent market rumours, often in offshore Friday trading, that a devaluation of the Hong Kong dollar or Chinese renminbi would occur over the weekend'.

${ }^{4}$ In their theoretical discussion, Corsetti et. al. recognize that large players can influence market outcomes, but appear reluctant to hypothesize that this occurred in Hong Kong's case. Their formal analyses deal with speculative attacks in a single market, and they then informally extrapolate their results to the HK case. However, in a double-play situation, if a devaluation does not occur, speculators can either lose or gain (Corsetti et.
} 
The foregoing account permits (preliminary) identification of areas of vulnerability to speculative attack, or fault lines, in the Hong Kong environment of 1997-98. The first is the commitment to a fixed exchange rate. The Hong Kong authorities probably felt that they had no alternative in the matter, since any devaluation so soon after the accession to China could, it was felt, trigger a massive loss of confidence - a multiple-equilibria scenario analogous to Diamond-Dybvig-style bank panics, but affecting asset (including stock) prices in Hong Kong's case. ${ }^{5}$ (Instead, real GDP grew by 3\% in 1999 and 10.2\% in 2000.) In more 'normal' situations, however, an adjustable peg (a) provides, as is well-known, speculators with a one-way bet (especially if the band around the peg is fairly narrow), and (b) does not permit gradual exchange rate adjustments in the light of slowly changing fundamentals. Second, is the ease with which speculators could borrow Hong Kong dollars, either in the interbank market or from multilateral institutions. Third, is the unrestricted ease of short-selling, in stock spot and index futures markets, and the laxity in the enforcement of settlement requirements. Last is the initial small size of the monetary base, coupled with reliance on the autopilot mechanism of the $\mathrm{CB}$

al. simply assume that they will lose), depending on the actions of other speculators and of the authorities, which affect interest rates and present and future stock prices. It is also entirely conceivable that in the Hong Kong case speculators failed to fully anticipate the extent and nature of the authorities' reaction. Rzepkowski (p. 28) adopts a somewhat similar view of the underlying process to ours, arguing that 'the logic underlying the several attacks against the HK dollar rests essentially on self-fulfilling expectations and on a pure contagion'. Next, Chakravorti and Lall (2000) formally model a speculative double-play, and conclude ( $p .23$ ) that 'government intervention in the equity market may either reduce interest rate or reduce the downward price pressure in equity markets but not both', owing to countervailing actions by speculators. They very peculiarly assume, however, that such intervention has no monetary effects, contrary to Rzepkowski's observation earlier, and they also overlook that in Hong Kong, as indicated above, a fairly large sum of nonmonetary reserves was converted into Hong Kong dollars to meet fiscal obligations. A useful policy lesson here is that, if intervention is to be undertaken in response to a double-play, it should also be targeted at both equities and money markets.

${ }^{5}$ This is a possibility which Devereux (2003) does not address, in his comparison of the implications of the differing exchange rate regimes of Hong Kong and Singapore for longer run trends in inflation and real exchange rates, and for short-run macroeconomic and real exchange rate volatility. It is also not clear whether his short-run simulation analysis imposes expectational rationality with regards to the exchange rate (equal, in his model, to the expected rate of inflation of traded-goods prices) and the price of land. 
system. $^{6}$ We turn now to a discussion of some of Singapore's experiences with capital flow volatility, and we should also recognize that not infrequently a tension exists between the desire for short-run stability, and the desire to foster deeper and more open financial and capital markets for purposes of long-run growth and development of the economy.

\section{Singapore - policy background and early experience}

Any discussion of Singapore's experience must assign a prominent place to a major, long-standing (but recently relaxed, as discussed below) cornerstone of its monetary policy - the policy of non-internationalization of the Singapore dollar. ${ }^{7}$ In MAS Notice 621 of November 1, 1983, the Monetary Authority of Singapore (MAS) stated:

'Banks should observe the Authority's policy of discouraging the internationalization of the Singapore dollar. Specifically, banks should consult with the Authority before considering Singapore dollar credit facilities exceeding S\$5 million (per entity) to nonresidents, or to residents where the Singapore dollars are to be used outside Singapore. Banks managing syndicated loans, bond issues, or other financial papers exceeding $\$ \$ 5$ million should do

\footnotetext{
${ }^{6}$ In his empirical work, Rzepkowski utilizes the information in currency option prices to infer the expected intensity of an HK dollar devaluation, and then, in a VAR framework, demonstrates the existence of a speculative double-play: 'A circular scheme characterized the formation of self-fulfilling expectations. The (expected) intensity of a HK dollar devaluation induced a sharp decrease in the index futures prices, which contributed to make the volatility of the HSI (Hang Seng Index) soar, in turn exacerbating the speculative pressures against the HK dollar' $(p .27)$. However, he then argues that the HKMA's stock market interventions in August 1998 were ineffective, since they 'achieved to push up temporarily the index futures price, but induced a significant rise in the market volatility' (ibid.). Instead, it was the technical measures introduced in September 1998 to strengthen the CB system ( $p .4$ above) which, he claims, dampened the pressures against the currency. Rzepkowski acknowledges that his options analysis abstracts from the possibility of a time-varying risk premium, and imposes 'strong assumptions on the underlying dynamics' (p. 29), and so the robustness of his findings remains an open issue.

${ }^{7}$ We draw here mainly on Chan and Ngiam (1996, 1998), but critique their formal analysis below, as well as on Lee (2001).
} 
likewise. The terms "residents" or "nonresidents" include bank and nonbank customers. $^{, 8}$

Chan and Ngiam (1996, p. 6) point out that, 'To ensure that its regulations are not being circumvented through financial derivatives, the MAS has defined Singapore dollar credit facilities to cover a wide range of financial instruments, including loans, foreign exchange swaps, currency swaps, interest rate swaps, facilities incorporating options, and forward rate agreements in Singapore dollars'. 9 Subsequently, on July 18 1992, the MAS issued a circular amending the policy. Consultation with the MAS was not required for credit facilities extended in Singapore dollars, in any amount, to residents or nonresidents to facilitate direct exports from and imports to Singapore, and for payment bonds in favour of Singapore parties, or payment guarantees, in respect of 'economic activities' in Singapore, where the latter specifically excluded financial and portfolio investments. Forward sales of Singapore dollars earned from exports to Singapore were also permitted.

At the same time, banks were told that they should not finance in Singapore dollars 'activities which have no bearing on Singapore' (op. cit., p. 5), including direct or portfolio investments outside Singapore by nonresidents, third-country trade by nonresident-controlled companies, and nonresident subscription to equity in a Singapore company where the proceeds are used for takeovers or financial investments. 'In addition, banks have been advised against granting Singapore-dollar credit facilities to nonresidents for speculating in the local financial and property markets' (ibid.). For all other activities - which are quite wide-ranging, and include third-country trade as well as direct and portfolio investments overseas by residents, and direct investment and housing

\footnotetext{
${ }^{8}$ Quoted in Chan and Ngiam $(1996$, p. 5). Singapore also has a very active offshore Asian Currency market (in non-Singapore currencies), and banks are required to maintain separate accounts for Asian Currency Units or ACU's (op. cit., p. 4). 'Nonresidents include Singapore-incorporated companies, which are majority-owned or otherwise controlled by nonresidents' (Lee, $p$. 34).

9 'Without any restrictions, a firm or individual can borrow Singapore dollars indirectly by first borrowing US dollars and then doing a foreign exchange swap (which involves the buying of the Singapore dollar spot with the simultaneous selling of the Singapore dollar forward). This effectively replicates, or synthesizes, a Singapore dollar money market loan with a "lock-in" Singapore dollar interest rate' (ibid.).
} 
development in Singapore by nonresidents - the 1983 ruling calling for consultation with the MAS continued to apply.

It perhaps bears noting that there are no restrictions against nonresidents building up Singapore dollar holdings by converting their own foreign-currency resources (or resources borrowed abroad) into Singapore dollars, and placing them with the DBUs (domestic banking units). Moreover, by 1994 'the ACUs and the banks outside Singapore have amassed some S\$51.6 billion worth of Singapore-dollar deposits (or 25 percent of total liabilities) in the DBUs' (op. cit., p. 7). Such S\$ holdings could be converted into foreign currencies if sentiment regarding the S\$ turns adverse: however, any further pressure through nonresidents borrowing domestic currency and converting it, as occurred in Hong Kong, is obviated. ${ }^{10}$ 'Further pressure' here refers not to any increased likelihood of the country's reserves being unable to support capital outflows which obviously cannot occur under a CB system - but to heightened short-term interest rates, and their effects on the economy, as well as the enhanced complexity of monetary management.

Commencing in August 1998, a series of steps was undertaken to gradually liberalize the non-internationalization policy, in conjunction with moves to promote the development of the S\$ bond market. These are discussed in greater detail below (Section V). Throughout, however, the MAS has made it clear that 'banks shall not extend S\$ credit facilities [exceeding $\mathrm{S} \$ 5$ million] to non-resident financial institutions if there is reason to believe that the S\$ proceeds may be used for S\$ currency speculation' (MAS (Revised) Notice 757 of 28 May 2004). In the Frequently Asked Questions accompanying this Notice, it was stated that banks 'are expected to institute appropriate

\footnotetext{
${ }^{10}$ Chan and Ngiam (1996, p. 8) also suggest that '(a)s the forward market involving the Singapore dollar is rather thin, it cannot provide an effective vehicle for speculation': moreover, the MAS monitors forward transactions with a view to ensuring that these are used for hedging and not for speculation. They further suggest that borrowing by residents for speculative purposes does 'not seem to be a major concern as the Government can bring them to task if they bring down the Singapore dollar' ( $f n$. 27): the point being made here probably relates to the greater ease of monitoring, and if necessary regulating, the activities of residents, and perhaps also the greater sophistication and speed of action of foreign hedge funds and the like.
} 
internal controls and processes to comply with this restriction': these may include 'written confirmation from the non-resident financial institution specifying the purpose of funding', and a 'formal evaluation process of the client profile, which provides a clear basis for assessing that the client is unlikely to use the S\$ proceeds for currency speculation'. Banks are also required to report to MAS monthly their aggregate outstanding S\$ lending to non-resident financial institutions. Clearly, there is an element of judgment involved in assessing that a client is 'unlikely' to engage in speculation, but to date this does not appear to have created difficulties for banks.

The non-internationalization policy has thus rather effectively blocked one of the channels of vulnerability that existed in Hong Kong. What about another channel, that of short-selling of shares ${ }^{11}$ ? This, too, is circumscribed in Singapore: Poitras (2002, p. 147) points out that 'sales for same day delivery' are permitted, and in its Report on Transparency of Short Selling (June 2003, p. 10) the Technical Committee of the International Organization of Securities Commissions (IOSCO) states that the Stock Exchange of Singapore (SES) 'may suspend individual securities if speculative activity is excessive or abuse is suspected'. ${ }^{12}$ We thus observe a role being assigned to discretion in decision-making, and both this and the same-day covering rule are in all likelihood reflective of the fact that the literature is not unambiguous regarding the net benefit of short-selling, especially in the presence of large players.

\footnotetext{
${ }^{11}$ As discussed below, stock index futures were only introduced in 1998.

${ }^{12}$ There appears to be some confusion of interpretation about the issue. Bris et. al. (2003, p. 33) say that in Singapore short-selling is 'not allowed' but is 'practiced', while Morgan Stanley (2003, p. 4) say, 'There are no by-laws under the SGX (Singapore Exchange Ltd) that forbid short-selling, however the present CDP (Central Depository) system actively works against it. This is because short sellers must cover their positions within the same day or face a buy-in by the SGX'. Poitras (op. cit.) says that 'Except in very restrictive circumstances, short selling of stock on the SES is prohibited', while the Technical Committee of IOSCO states (op. cit.) that short-selling is 'unrestricted', except for the caveat mentioned above. Market practitioners confirm, however, that short-sellers are expected to cover their positions by the end of the same day, after which a buy-in by the SGX can occur; as mentioned, suspension of individual securities can also be instituted.
} 
Discussion of the other two channels of vulnerability - the fixity of the exchange rate, and the narrowness of the monetary base - is best carried out in the light of Singapore's exchange rate experience in the 1980's. As Teh (1988) points out,

'The Singapore dollar exchange rate is managed and set against a tradeweighted basket of currencies of its major trading partners. The trade-weighted Singapore dollar is allowed to float within a target band. The MAS keeps the trade-weighted dollar within the band through foreign exchange interventions [in US\$]...The level at which the trade-weighted dollar is set is determined by what world inflation and domestic inflation are expected to be. Generally, the aim is to reduce imported inflation in domestic prices by appreciating the tradeweighted dollar. ${ }^{13}$

Departures from the foregoing general objective have occurred under recessionary conditions, during which the $\mathrm{S} \$$ has been permitted to depreciate to a certain extent. The first post-1965 recession in Singapore occurred in 1985, when real GDP fell by 1.6\%, followed by slow growth of 2.3\% in 1986 (Peebles and Wilson (2002)). In response, as Figure 1 shows, the S\$ depreciated gradually from 1985 to the beginning of 1987 . The depreciation was not an entirely smooth affair, however, as we now discuss.

It appears that speculators overestimated the extent to which the authorities were prepared to permit the exchange rate to depreciate. By August 1985, the S\$ had depreciated to about S\$2.20:US\$1 (from about S\$2.10:US\$1 earlier), and it then came under speculative pressure, primarily through spot conversions of S\$ into foreign currencies (Chan and Ngiam (1996), pp. 7-8) By Thursday September 12, it had fallen to almost \$2.31:US\$1 (Starr (1985)). The following Monday, the MAS intervened, by spending US $\$ 100$ million (amounting to less than $0.1 \%$ of its foreign reserves, according to Chan and Ngiam) to purchase S\$. The consequence was an immediate rise in the overnight interbank rate, which reached $120 \%$ on September 18 , and the S\$ strengthened

\footnotetext{
${ }^{13}$ As MAS (2000, p. 24) points out, under a pure CB system the rate used by the CB determines the market exchange rate, whereas in Singapore the exchange rates used by the $\mathrm{CB}$ 'depend on the current rates in the foreign exchange market'.
} 
to S\$2.20:US\$1 - an appreciation of about $5 \%$ in just 4 days. 'Substantial losses have almost certainly been incurred by foreign banks as a result of speculating against the Singapore dollar' (Textline, 1985). Thereafter, liquidity was gradually restored to the money market, but it was also made clear that the MAS would not hesitate to act again if necessary.

Clearly, in addition to the non-internationalization policy and the discouragement of speculative short-selling of shares, the exchange-rate policy played a significant role in defusing the speculative attack. Initially permitting the exchange rate to depreciate to S\$2.20:US\$1, in line with weakening fundamentals, took some of the edge off speculative pressure. It would appear that the authorities then permitted, for some time, a further depreciation owing to uncertainty regarding the path of fundamentals. When it was determined that this depreciation was excessive, they were in a position to inflict substantial losses on speculators. Like Hong Kong, Singapore's very healthy reserve position is a valuable asset in this regard. Unlike Hong Kong, however, non-adherence to a fixed peg implied that speculators faced a 'two-way bet': this may have constrained the intensity of the attack then, and by strengthening the MAS' reputation for toughness reduced their willingness to attack in the future as well. Finally, the flexibility with which the MAS generally permits short-term uncollateralized borrowing by banks, in support of its exchange rate policy (MAS, n.d., p. 6), meant that the speculative pressure prior to the MAS intervention did not appreciably raise short-term interest rates (Textline, ibid.). We proceed next to examine lessons learnt during the Asian Crisis of 1997-98. ${ }^{14}$

\footnotetext{
${ }^{14}$ Chan and Ngiam's (1998) formal analysis of the 1985 episode appears, however, to be flawed. They erroneously assume that the exchange rate was appreciated from a preexisting disequilibrium level, but that interest rates nonetheless fell because, by underscoring the authorities' determination not to allow the currency to weaken, it reduced the perceived probability of a devaluation. In fact, however, interest rates did as indicated above rise after the appreciation, owing to the liquidity squeeze, and only fell subsequently. The key element of losses imposed on speculators by the appreciation is not included in their analysis, and neither do they recognize that the appreciation was intended to bring the exchange rate to an (equilibrium?) level that was lower than the S\$2.10 level originally. Indeed, it is difficult to imagine the perceived devaluation probability, and the interest rate, falling, for good, if the exchange rate did indeed remain overvalued.
} 


\section{Singapore - the 1997 experience}

We begin with a succinct statement by Chan and Ngiam (1998, p. 259):

'During the recent Asian currency crisis, which began when Thailand allowed its baht to float on July 2, 1997, the Singapore dollar, along with all the regional currencies, showed a significant fall against the US dollar for six months. From a high of $\$ 1.43$ per US dollar on the day before the float of the baht, the Singapore dollar went all the way down to S\$1.75 per US dollar on January 7, 1998, a decline of 18.3 percent over the period...Although the Singapore dollar depreciated against the US dollar, it appreciated sharply against the regional currencies. Hence, on a trade-weighted basis, the Singapore dollar actually showed a slight appreciation since July 1, 1997. The Singapore dollar has withstood the currency storm lashing the region because of its extremely strong economic fundamentals..(including) low foreign debt, huge foreign exchange reserves, large current account surpluses, substantial budget surpluses, high savings rates, strong inflow of foreign direct investment, a sound financial system and prudent government policies.'

We thus observe a significant difference between Singapore's exchange rate experience in 1997 and its experience in 1985. The greater depreciation in 1997, compared to the initial depreciation of only about $5 \%$ from $\mathrm{S} \$ 2.10$ to $\mathrm{S} \$ 2.20$ per US\$ in 1985, might have reflected a judgment that the economic situation was more serious in 1997: at the same time, a larger depreciation might have been more in line with speculators' priors, and the latter might also still have had memories of the 1985 experience. $^{15}$ In both years, the non-internationalization policy and the short-sale restrictions would also have helped. Singapore's experience also exemplifies the point

\footnotetext{
${ }^{15}$ Hashimoto (2003, p. 256) obtains 'puzzling' results in seeking to identify speculative pressure against the $\mathrm{S} \$$ in 1997, including the fact that a large depreciation occurred when her estimated depreciation likelihood was lowest. Methodologically, her assumption that speculators condition only on the M2/foreign exchange reserves ratio in deciding when to launch an attack appears rather restrictive, and it is also not clear what her estimated critical level of 0.25 for this ratio for Singapore signifies, since the actual ratio was above this throughout her sample period (1986-97).
} 
made earlier (p. 6) regarding the merits of gradual rather than discrete adjustments in situations that are not too extreme.

Notwithstanding the fairly smooth exchange rate adjustment, Singapore was not spared from volatility in other asset markets, particularly equities and property. From a high of 2055.44 in January 1997, the Straits Times Index of stock prices dropped by $60 \%$ to 856.43 in September 1998 before recovering (Ngiam, 2000, p. 6, and his Figure 2). The private property price index dropped monotonically by about $40 \%$ from 270.0 in the first quarter of 1997 to 163.7 in the fourth quarter of 1998 (ibid., and his Figure 3). Real GDP in fact declined by $0.9 \%$ in 1998 (Table 1 below). It would not be correct to ascribe these developments solely to contagion effects, and trade and banking exposure to the region. Other factors, such as the global electronics slowdown, the downturn in the domestic real estate cycle, and (over time) the gradually increasing competition from China and India, also played a significant part. However, Singapore's experience in 1997-98 underscores the fact that countries that 'plug into' the global economic grid will tend to experience not only higher mean growth rates, but also greater variability of those growth rates. As has often been noted, capital can flow out of a country, as well as into it. Selective measures aimed at particular sectors can mitigate the degree of volatility, but are unlikely to be capable of effectively eliminating it. Of course, economic agents will in due course learn to make improved risk-return calculations, and at the same time governments would be well-advised to develop various coping mechanisms, such as a reasonable degree of social insurance, and provision of skills upgrading and re-training facilities, to help those who are severely affected by shorter-term cyclical, as well as longer-term structural, changes.

\section{Debt Markets in Singapore}

We begin with some figures, for the 1990's. Table 2, from Ong (1998), provides information on the debt-to-asset ratio (DAR) of nonfinancial corporations in Singapore, Canada, and the U.S. The ratio in Singapore has declined somewhat in the 1990's, and is fairly modest at 0.31 , of which 0.21 is due to short-term debt (defined as 'the sum of bank loans and overdrafts, short-term commercial papers and other short-term loans' (op. cit., 
p. 9)), and 0.10 to long-term debt ('the sum of preference shares, bonds and debentures, and other long-term loans' (ibid.)).

With regards to external debt, the Singapore Department of Statistics (SDOS) distinguishes between external debt per se - defined as 'all overseas loans drawn by our corporate, government and household sectors, but excludes our banks' overseas interbank loans' (2000, p. 1; we discuss bank borrowing below) - and 'secondary forms of external debt', comprising negotiable 'debt securities' (SDOS, 1998, p. 2) such as bonds, debentures, and treasury bills, and trade credits ('direct extension of credit by suppliers and buyers for goods and services transactions and advance payments for work that is in progress' (ibid.)). Tables 3-8 provide information on these, during the 1990's. 'Singapore has had no public external debt since 1995' (SDOS (1998), p. 2), owing to its regular budget surpluses. Its debt sustainability ratios have been much more favourable than those of other countries in the region. About three-quarters of the external corporate debt was contracted by foreign-owned companies. ${ }^{16}$

Turning to secondary forms of external debt, SDOS (2000) observes, in regards to Table 7, 'Singapore's external liability in debt securities nearly doubled from $\$ 2.0$ billion at end-95 to $\$ 3.7$ billion at end-98...It was dominated by 4 foreign (3 Japanese and 1 U.S.) companies. The debt securities are mostly short and medium term notes issued to provide additional funds for the companies' operation'. Regarding FDI non-equity liabilities, and excluding debt securities, a significant portion comprised loans from parent companies. After 1995, Singapore was a net creditor in all trade credit transactions (FDI and non-FDI). As Table 8 shows, it was also a net creditor in all the other categories covered in the preceding tables, namely debt securities, FDI-related loans, and Loans to Other Non-Residents, with the exception of borrowing from external banks (Table 3): the figure of almost $\mathrm{S} \$ 12$ billion here is modest relative to other figures below, and has not been netted against lending by Singapore banks to external nonbank entities, on which data is not provided.

\footnotetext{
${ }^{16}$ The figure for nonbank loans at end-97, \$4.518 billion, is the same in Tables 3 and 6 , but the figure for bank loans is larger in the former, since it includes loans to households as well: nonbank lending to households is not significant.
} 
The overall picture that emerges is that of a comfortable external debt position, as far as nonbank entities are concerned. Turning to banks, ${ }^{17}$ as of December 1997 the DBU's owed S\$94.7 billion to banks outside Singapore (including to the head offices of foreignowned banks): however, they had also lent $\mathbf{\$} \$ 69.7$ billion to banks outside Singapore (both figures are inclusive of DBU transactions with ACU's, and all figures are from the Monthly Digest of Statistics, Singapore, July 1998). The total asset base of DBU's at that time (after deducting interbank lending between DBU's, but inclusive of dealings with ACU's and other foreign banks) was S\$163.7 billion, and their total deposits from nonbank customers amounted to $\mathrm{S} \$ 124.1$ billion, with a further $\mathrm{S} \$ 25.8$ billion of deposits with the Post Office Savings Bank (ibid.). Also by way of comparison, Singapore's stock market capitalization was about S\$180 billion in 1997 (Thiam, 2002, Table 1), notwithstanding the depressed state of security prices then. Finally, with regards to bond issuance specifically, total outstanding corporate bonds at that time, sold to both domestic and foreign asset-holders, amounted to S\$8.4 billion ( $\$$ \$6.7 billion being $\mathrm{S} \$$ issuance, and $\mathrm{S} \$ 1.7$ billion being non-S\$ issuance), and total outstanding governmental debt (secondary debt according to the DOS classification) comprised S\$15.0 billion worth of bonds, and S\$6.9 billion worth of Treasury Bills (all figures from the MAS website, sections on Singapore's bond markets).

Given Singapore's modest overall external debt position, its large foreign exchange reserves (amounting to about six times the size of the monetary base ${ }^{18}$ ), and its small

\footnotetext{
${ }^{17}$ We focus here on DBU's, since the offshore market or the ACU's transact virtually entirely in foreign currencies.

${ }^{18}$ These very large reserves are to a not insignificant degree a reflection of Singapore's fairly low domestic absorption capacity (given its small size), juxtaposed against its large savings rate over many years. Nor does it appear that such large reserve holdings impose a significant opportunity cost on the economy: a Straits Times (Singapore) report of July 222004 by Audrey Tan quotes the Assistant Managing Director of the MAS, Ong Chong Tee, as saying 'we are invested across a diversified range of markets and currencies', and that, owing to 'the better performance of global equity markets' MAS' profits in the year ended March 312004 jumped to S\$4.99 billion (from just S\$623 million the previous year). The bulk of these profits arose from investing its foreign reserves, which totaled US\$96.3 billion at the beginning of the year. The report adds that 'MAS does not disclose the rate of return on its investments', but that, according to Mr Ong, 'on average, MAS' performance would place it in the top $25^{\text {th }}$ percentile of its peer group of fund
} 
exchange rate depreciation relative to that of other countries in the region, it is not surprising that its external indebtedness was not a noticeable aggravating factor in the 1997-98 downturn. It is, however, of interest to examine the reasons for the historical underdevelopment of Singapore's bond markets (as seen above, its banking system and equities market are much more developed), and to review the measures taken since 1998 to foster their growth, with particular reference to their implications for the S\$ noninternationalization policy. ${ }^{19}$

We may divide the reasons for the historical underdevelopment into supply and demand factors, while recognizing that there is some interaction between the two. Perhaps the most important supply factor has been the healthy fiscal position of the government, which has resulted in a limited need for it to issue bonds. Moreover, the bonds that were issued were of low maturity (not more than 7 years, prior to 1998), and the bulk of them, and of Treasury Bills, were held by banks and finance companies (to a significant extent to meet minimum liquidity requirements), as well as insurance companies, resulting in a very limited secondary bond market. (It should, however, be noted that we exclude here 'specially-issued, non-tradable, long-term government bonds which are held by the CPF (Central Provident Fund) until maturity' (Ngiam and Loh, $p$. 6). The CPF is Singapore's compulsory saving scheme, and its holdings of these special bonds substantially exceeds the outstanding amount of other, tradable government securities: Ngiam and Loh add, 'Most of the proceeds from such (CPF-purchased) bonds are probably channeled to the Government of Singapore Investment Corporation (GSIC) for investment in foreign assets' (ibid.).)

An important consequence of the underdevelopment of the governmental bond market, particularly the secondary market, was the absence of a benchmark yield curve to facilitate corporate issuance, and active trading, of bonds. At the same time, it may be

managers'. Substantial sums are also invested by the Government of Singapore Investment Corporation (in financial and real assets abroad) and Temasek Holdings (mostly in government-linked-companies domestically), but the precise amounts are not known, and neither is the former's rate of return on its investments.

${ }^{19}$ Valuable references here are Ngiam and Loh (2002), Lee (2001), and US Embassy, Singapore (2001). 
hypothesized that Singaporeans' 'appetite' for a secure, long-term asset has to a large extent been met, albeit compulsorily, by their CPF savings, notwithstanding the somewhat low return on such savings (Asher (2004)). They may thus wish to channel most if not all of their remaining, discretionary savings (beyond that used to finance home ownership) to more liquid bank deposits and to higher-yielding but risky equity investments, which helps to account for the more advanced state of development of Singapore's banking system and equities market - which in turn makes it easier for Singapore corporations to raise funds from these sources.

With a largely captive market for government securities, the government could afford to pay low yields on these, and in addition 'Singapore investors have to pay tax on interest income whereas they do not have to pay tax on capital gains obtained from investing in equities and properties' (Ngiam and Loh, p. 11). Lastly, much of Singapore's economic growth has historically been driven by large inflows of FDI, with foreign-owned companies receiving major infusions of equity and loans from their parent companies.

The Asian Crisis of $1997-98$ provided a major impetus to a shift in policy thinking regarding bond market development in Singapore. The Crisis had highlighted the dangers of currency and maturity mismatches in corporate borrowing, and Singapore banks had also suffered losses due to exposure to the region, although none was in danger of collapsing. It therefore appeared prudent to diversify the sources of, particularly longterm, borrowing on the part of Singapore corporations, and encourage them to borrow in S\$. Also, with economic growth the pool of discretionary saving was growing substantially, notwithstanding the high CPF contribution rate, and fund management companies had become increasingly active in the economy. One may surmise that concomitantly the demand for market determination of bond yields, and of greater market liquidity, was also growing. This was underscored by the severe fall in equity and property prices during the Crisis. From a longer-term, developmental perspective, fostering of a further pillar of Singapore's dynamic financial sector was also deemed desirable. The intention was to encourage not only Singaporean but also foreign corporations, and multilateral institutions, to float bond issues in Singapore. 
Accordingly, since 1999 the MAS has issued, on a regular basis, more Singapore Government Securities (SGS), with larger issuances and longer maturities (up to 15 years). The healthy fiscal position of the government has enabled it to offer lower yields on such securities, and yet ensure their acceptance by investors. ${ }^{20}$ Statutory boards and government-linked corporations (GLC's) have also become active in bond issuance, relying less on bank borrowing: for example, the Jurong Town Corporation launched a S\$200 million 12-year issue in 2000, and Singapore Telecommunications launched a S\$1 billion 5-year issue in February 2001. The intention has been 'to stimulate the emergence of a debt market, and to establish benchmark rates' (US Embassy, $p$. 2). Secondary market are still fairly small (Ngiam and Loh), although growing. Tax exemption for fee income earned by financial institutions arranging debt securities in Singapore (in S\$ as well as foreign currencies) was also granted, interest income earned by non-residents was exempted from withholding tax, and a concessionary tax rate of $10 \%$ was introduced on interest income earned by financial institutions and corporations from holding debt securities. Interest rate futures contracts were introduced, and restrictions on S\$ OTC (over the counter) interest rate derivatives such as interest rate swaps, forward rate agreements, and interest rate and swap options lifted (Ngiam and Loh, $p .13$ ). ${ }^{21}$ Primary and secondary market liquidity has also been sought to be fostered through measures such as the introduction of an SGS (Singapore Government Securities) repo facility for primary dealers, and of a 5-year SGS bond futures contract.

${ }^{20}$ See Figures 2 and 3 below (from Wong (2004)), in respect of Singapore and US Government 10-year bond yields in the recent past. The former has almost invariably been below the latter, while tracking its movement fairly closely, except in recent months, which Wong attributes to expectations of continued weakening of the US\$. The IMF Country Report No. 01/177 of October 2001 on Singapore also points out ( $p$. 24) that SGS offer lower yields than US Treasury bonds, but have nonetheless been included in J.P. Morgan's GBI (Government Bond Index) Broad since April 2001 (with a weight of $1 / 3$ percent), on account of their low cross-correlations with returns from most other government bonds, and their very low volatility of returns, "which help to expand the efficient portfolio frontier for bonds'. McCauley and Jiang (2004) provide a detailed analysis of the diversification benefits from holding a range of Asian-currency bonds, in addition to those from other areas.

21 'However, banks are required to submit monthly reports on details of interest rate derivative transactions exceeding S\$5 million with counter-parties outside Singapore' (ibid.). 
Of particular interest for our purpose is 'the opening up of the $\mathrm{S} \$$ bond market to foreign issuers..accomplished through MAS Notice 757, introduced in August 1998 and amended in November 1999' (Ngiam and Loh, $p .8){ }^{22}$ The proceeds from such issues could be retained in the form of S\$ deposits with banks in Singapore pending use: however, if and when the proceeds were to be used outside Singapore, they had to be converted or swapped into foreign currency before remitting abroad (ibid.). Funds raised for use in Singapore by nonbank nonresidents for designated economic activities (excluding, for example, 'speculating in the S\$ currency and interest rate markets' (Lee, p. 36)) did not require prior MAS approval. Prior approval was also not required for transacting in several derivative products (fuller details are provided in the Annex below). 'Moreover, Notice 757 (of August 1998) fully liberalized the extension of S\$ credit facilities to residents' (ibid., p. 35). Interestingly, in the revised Notice 757 of May 28 2004, the MAS has stated that, with effect from that date, nonresident nonfinancial issuers of S\$ bonds and equities were no longer required to swap or convert their S\$ proceeds into foreign currencies before remitting abroad, adding that this 'would allow the issuers greater flexibility in managing their S\$ funds'. For nonresident financial institutions, however, the requirement was retained.

'Shortly after this policy [of August 1998] was announced, the International Finance Corporation became the first foreign entity to issue $\mathrm{S} \$$ bonds, with a $\mathrm{S} \$ 300$ million threeyear issue. GE Capital followed in Q1 1999 as the first foreign private issuer, with a S\$300 million issue, followed by the Nordic Investment Bank and the European Bank for Reconstruction and Development. A wide range of foreign financial institutions and other corporates have launched issues since early 1999 (including US issuers such as Ford Motor Credit, JP Morgan, UPS, Morgan Stanley, John Hancock, General Motors Acceptance, and Goldman Sachs, as well as a wide range of European entities and some Asian entities)' (US Embassy, p. 3). By the first quarter of 2002, total S\$ bond issue by foreign entities amounted to S\$7.2 billion (Ngiam and Loh, p. 8), and the market

\footnotetext{
${ }^{22}$ Foreign entities have also been permitted to list S\$-denominated shares since late 1998, but similar restrictions to those discussed immediately below in regards to the use of the proceeds outside Singapore applied (Shook Lin and Bok, 2001).
} 
continues to grow, thereby helping to meet the demand of both domestic and foreign investors (including fund managers) for such instruments.

Ngiam and Loh further mention (p. 20) that 'from December 2000 onwards, nonresidents have been allowed to borrow Singapore dollars (from banks) to buy SGS and SDCB (Singapore Dollar Corporate Bonds)', as well as S\$ equities and real estate (US Embassy). Banks were also permitted to 'extend S\$ credit facilities exceeding S\$5 million to nonresidents to fund offshore activities, as long as the S\$ proceeds are swapped into foreign currency' (Lee, $p .37$ ), to transact in $\mathrm{S} \$$ currency options with other banks and financial institutions in Singapore, and to transact with nonresidents in a broad range of derivative products ( $\mathrm{op}$. cit.; the Annex below provides further details). Foreign securities intermediaries were permitted to freely obtain S\$ financing domestically, and, effective March 1 2001, offshore banks were permitted to freely engage in S\$ swap activity with nonbanks (US Embassy). In March 2002, S\$ credit facilities to nonresident nonfinancial entities (such as corporate treasury centers) were liberalized, so that only credit in excess of S\$5 million to nonresident financial entities for speculating against the S\$ was prohibited, and even the latter were permitted to engage in a wider range of derivative transactions (such as S\$ currency options) with financial institutions. The intention was to promote the deepening of such markets. We discuss the overall implications of measures to promote financial market development in the Conclusion.

\section{Conclusion}

Singapore clearly has strong defenses against what it deems to be excessive exchange rate volatility triggered by 'destabilizing' capital flows. These include its strong fundamentals (discussed by Chan and Ngiam above (p. 13)), the adoption of a CB system, and the non-adherence to a fixed currency peg when the economic situation changes. (Indeed, an important lesson is that it is the package of policies in totality that can meaningfully be evaluated, rather than individual policies in isolation from the overall policy context.) Under the imperative of promoting the continued growth and diversification of its financial sector - an important pillar of the economy, accounting for about $12 \%$ of its GDP - quite a number of administrative restrictions have been relaxed 
since 1997. This was heralded in a key address on November 41997 by then Deputy Prime Minister Lee Hsien Loong. 'In order to meet the upcoming challenges, DPM Lee proposed a fundamental change in Singapore's attitude towards risk management...In contrast to Hong Kong, "where anything not expressly forbidden is permitted", Lee noted that in Singapore "anything not expressly permitted is forbidden". At this stage, however, the government needed to regulate the financial sector "with a lighter touch, accept more calculated risks, and give the industry more room to innovate and stretch the envelope" in order to promote a more competitive, dynamic and innovative environment. Lee argued for a disclosure-based regulatory system to protect investors, rather than..extensive regulations' (US Embassy, Singapore, 1999).

The progressive relaxations of the S\$ non-internationalization policy, which in any event was a rather limited form of capital control, ${ }^{23}$ may be viewed in this light. Such relaxations, including those on a wide variety of derivative transactions, were necessary to foster bond market development in Singapore, and the evidence provided above indicates that this objective (including the attraction of foreign bond-issuers) is well on the way to being achieved. Since May 2004, the only remaining restriction of any significance is the onus placed on banks to determine, as far as possible, that the S\$ credit facilities they extend to non-resident financial institutions will not be used for currency speculation. This would appear to be a reasonable restriction, especially in the light of the very high interest rate volatility experienced by Hong Kong, which does not impose such a restriction, during speculative periods ( $p p$. 2-3 above). Given the MAS' reputation for toughness, one would expect that banks will err on the side of caution in implementing this policy. Financial market development is thereby facilitated, and at the same time the risk of heightened currency speculation during turbulent periods, and the associated macro-economic instability, is reduced. It is also quite conceivable that restrictions, for example on swap transactions, would be re-introduced if it was felt that the situation so warranted.

\footnotetext{
${ }^{23}$ A study by the MAS (2000) found that during the 1990's, and prior to the Asian crisis, covered and uncovered interest parity tended to hold between Singapore and US 1- and 3month interbank rates respectively, indicating, as one might expect, a high degree of financial integration.
} 
A similar policy orientation may be seen in the securities market. In 1998, Morgan Stanley launched the MSCI Singapore stock index futures contract, and in 2000 the Straits Times Singapore stock index futures contract was launched, both on SIMEX (Singapore International Monetary Exchange). However, SIMEX is authorized by the MAS to 'establish position and trading limits to diminish or prevent excessive speculation' (Lawton, 1999, Section 3), and also maintains a large trader reporting system. Somewhat ironically, in the light of DPM Lee's observations, while Singapore has moved to a more relaxed regulatory regime, Hong Kong has 'tightened up' somewhat, and the two systems are closer than they previously were. This perhaps is where the golden mean lies - a fairly, although not completely, unrestrictive, rule-based system in general, but with provision for discretionary intervention when the situation warrants. Do such discretionary provisions create uncertainty for business, and can they be abused? If they are intelligently employed, they can be very valuable in times of stress, and perhaps the best safeguard against abuse is public analysis and discussion whenever they are employed.

\section{Annex: Chronology of Capital Controls in Singapore}

\section{June 11978}

Exchange controls were completely liberalized, in line with efforts to develop Singapore as a banking and financial centre (including offshore banking). From then on, 'residents are allowed to borrow, lend and invest freely in foreign currencies. Banks in Singapore that are licensed to deal in Asian Currency Units can freely accept deposits in foreign currencies. Residents may deal freely in spot and forward foreign exchange transactions. Non-residents are freely allowed to make direct and portfolio investments in the country' (MAS (1999), p. 2).

\section{November 11983}

MAS Notice 621, setting out the policy of non-internationalization of the Singapore dollar, issued ( $p p$. 7-8 above).

\section{July 181992}

The MAS amends the policy by distinguishing three categories of activities: 
(i) The approved category: consultation with the MAS was not required for credit facilities extended in $\mathrm{S} \$$, in any amount, to residents or nonresidents to facilitate direct exports from and imports to Singapore, and for payment bonds in favour of Singapore parties, or payment guarantees (including guarantees for tax payments), in respect of 'economic activities' in Singapore, where the latter specifically excluded financial and portfolio investments. Forward sales of Singapore dollars earned from exports to Singapore were also permitted.

(ii) The banned category: banks were not to finance in S\$ 'activities which have no bearing on Singapore', including direct or portfolio investments outside Singapore by nonresidents, third-country trade by nonresident-controlled companies, and nonresident subscription to equity in a Singapore company where the proceeds are used for takeovers or financial investments. Banks were also not to extend S\$ credit facilities, in any amounts, to nonresidents for speculating in the local financial and property markets.

(iii) The unlisted category: for all other activities - which are quite wide-ranging, and include third-country trade as well as direct and portfolio investments overseas by residents, and direct investment and housing development in Singapore by nonresidents - the 1983 ruling calling for consultation with the MAS continued to apply.

\section{August 1998}

In conjunction with an 'extensive program of financial sector liberalization' (Lee, $p$. 35), the MAS issues the first version of Notice 757, which replaced Notice 621: this and subsequent versions sought to successively relax restrictions against various financial transactions. While concluding that 'the basic policy remains sound', the MAS stated that 'some judicious relaxation of specific restrictions would foster the development of capital markets with minimal incremental risks' (quoted in Lee, op. cit.).

The Notice fully liberalized the extension of S\$ credit facilities to residents. In addition, banks could now engage in the following activities without prior consultation with the MAS (ibid.):

(i) Extension of S\$ credit facilities to, and arranging $\mathrm{S} \$$ equity listings or bond issues for, nonbank nonresidents if the $\mathrm{S} \$$ proceeds are used for designated economic activities in Singapore.

(ii) Extension of $\mathrm{S} \$$ credit facilities to nonbank nonresidents for financial investments - shares, bonds, deposits, and commercial properties in Singapore - up to $\mathrm{S} \$ 5$ million.

(iii) Extension of $\mathrm{S} \$$ credit facilities up to $\mathrm{S} \$ 20$ million to nonresidents, via repurchase agreements of Singapore Government Securities (SGS).

(iv) Engaging in a limited list of derivative transactions, including hedging of currency or interest rates from the activities listed in (i) above, and transacting in $\mathrm{S} \$$ interest rate futures with nonresidents. 
For other activities, consultation with the MAS continued to be required, and in addition the S\$ proceeds from credit facilities and bond and equity listings arranged for nonbank nonresidents had to be converted or swapped into foreign currency if they were to be used outside Singapore. Also, the extension of S\$ credit facilities to nonresidents for certain purposes - including speculating in the S\$ currency and interest rate markets, financing third-country trades, and financing acquisition of shares of companies not listed on the Stock Exchange or Central Limit Order Book - was explicitly prohibited.

\section{November 1999}

Banks were permitted to engage in an expanded range of activities without prior consultation with the MAS, including extension of S\$ credit facilities to, and transacting in S\$ interest rate products with, other banks, merchant banks, finance companies, and insurance companies in Singapore; extension of $\mathrm{S} \$$ credit facilities of any amount to nonresidents via repos of SGS or other S\$ bonds; arranging S\$ equity listings for nonresident companies as long as the $\mathrm{S} \$$ proceeds were converted into foreign currency before being used outside Singapore; and all S\$ derivative transactions with residents, as well as an expanded range of derivative transactions with nonresidents, including optionrelated products with nonfinancial counterparts. However, banks were still required to consult with the MAS before transacting in S\$ currency options or option-related products with nonbank financial institutions, and before extending S\$ credit facilities exceeding S\$5 million to banks and other financial institutions outside Singapore, and were not permitted to transact in S\$ currency options or option-related products with other banks.

\section{December 2000}

Nonresidents were permitted to borrow Singapore dollars (from banks) to buy SGS and SDCB (Singapore Dollar Corporate Bonds), as well as S\$ equities and real estate. Banks were also permitted to extend $\mathrm{S} \$$ credit facilities exceeding $\mathrm{S} \$ 5$ million to nonresidents to fund offshore activities, as long as the S\$ proceeds are swapped into foreign currency, to transact in S\$ currency options with other banks and financial institutions in Singapore, and to transact with nonresidents in a broad range of derivative products, including crosscurrency swaps and currency options for hedging purposes, S\$ interest rate derivatives, and equity derivatives. Foreign securities intermediaries were permitted to freely obtain S\$ financing domestically, and, effective March 1 2001, offshore banks were permitted to engage freely in S\$ swap activity with nonbanks.

\section{March 2002}

S\$ credit facilities to nonresident nonfinancial entities (such as corporate treasury centers) were liberalized, so that only credit in excess of S\$5 million to nonresident financial entities, including banks, finance companies, insurance companies, hedge funds, and securities dealers and brokers, for speculating against the S\$ was prohibited. Even the latter entities were permitted to engage in a wider range of derivative transactions (such as S\$ currency options) with financial institutions, except that foreign exchange 
swaps involving a spot sale of $\mathrm{S} \$$ to the nonresident in the first leg remained under the rubric of S\$ credit facilities. Apart from this, transactions involving asset swaps, crosscurrency swaps and cross-currency repos were fully liberalized. The intention was to promote the deepening of such markets, and make it easier for S\$ equities and debts to be swapped into foreign currencies for overseas use. Financial institutions were also no longer required to ensure that $\mathrm{S} \$$ credit facilities extended to finance investments be withdrawn when the investments were liquidated, thereby lessening the burden of tracking fund use.

\section{May 282004}

Nonresident nonfinancial issuers of $\mathrm{S} \$$ bonds and equities were no longer required to swap or convert their S\$ proceeds into foreign currencies before remitting abroad, so as to 'allow the issuers greater flexibility in managing their S\$ funds'. For nonresident financial institutions, however, the requirement was retained, in respect of S\$ proceeds from equity and bond listings, as well as from borrowing from banks. Banks are also required to report to MAS monthly their aggregate outstanding S\$ lending to non-resident financial institutions. It was reiterated that 'banks shall not extend $\mathrm{S} \$$ credit facilities [exceeding S\$5 million] to non-resident financial institutions if there is reason to believe that the $\mathrm{S} \$$ proceeds may be used for $\mathrm{S} \$$ currency speculation'. 


\section{References}

Asher, M., 'Retirement Financing in Singapore', mimeo., School of Public Policy, National University of Singapore, June 2004

Bris, A., Goetzmann, W. N., and Zhu, N., 'Efficiency and the Bear: Short Sales and Markets around the World', NBER Working Paper No. W9466, January 2003

Chakravorti, S., and Lall, S., 'The Double Play: Simultaneous Speculative Attacks on Currency and Equity Markets', Federal Reserve Bank of Chicago Working Paper WP2000 - 17, December 2000

Chan, K.S., and Ngiam, K.J., 'Currency Speculation and the Optimum Control of Bank Lending in Singapore Dollars: a Case for Partial Liberalization', International Monetary Fund Working Paper WP/96/95, August 1996

Chan, K.S., and Ngiam, K.J., 'Currency Crises and the Modified Currency Board System in Singapore', Pacific Economic Review, 3(3), October 1998, 243-63

Corsetti, G., Pesenti, P.A., and Roubini, N., 'The Role of Large Players in Currency Crises', NBER Working Paper No. W8303, May 2001

Devereux, M.B., 'A Tale of Two Currencies: the Asian Crisis and the Exchange Rate Regimes of Hong Kong and Singapore', Review of International Economics, 11(1), February 2003, 38-54

Dickens, M., 'Development of the Hong Kong Securities and Futures Market', Fourth Round Table on Capital Market Reform in Asia, organized by OECD and the ADB Institute, April 2002, Tokyo

Financial Stability Forum, Report of the Working Group on Highly Leveraged Institutions, April 2000

Hashimoto, Y., 'An Empirical Test of Likelihood and Timing of Speculative Attacks: the case of Malaysia and Singapore', Japan and the World Economy, 15(2), 2003, 245-59

Hashimoto, Y., and T. Ito, 'High-Frequency Contagion between the Exchange Rates and Stock Prices', NBER Working Paper No. 10448, April 2004

International Monetary Fund, 'Singapore: Selected Issues', IMF Country Report No. 01/177, October 2001

Lawton, J.C. (Acting Director, Commodity Futures Trading Commission, USA), Letter to J.K. Thorpe, 'Singapore International Monetary Exchange Limited; Request for NoAction Relief from the Contract Market Designation Requirement', December 17, 1999 
Lee, J., 'Evolution of the Policy on Noninternationalization of the Singapore Dollar', Section IV of International Monetary Fund (2001)

McCauley, R., and G. Jiang, 'Diversifying with Asian Local Currency Bonds', BIS Quarterly Review, September 2004, 51-66

Monetary Authority of Singapore, 'Monetary Policy Operating Procedures in Singapore', BIS Policy Paper, n.d., 1-10

Monetary Authority of Singapore, Capital Account and Exchange Rate Management in a Surplus Economy: The Case of Singapore, Occasional Paper No. 11, March 1999

Monetary Authority of Singapore, A Survey of Singapore's Monetary History, Occasional Paper No. 18, January 2000

Monetary Authority of Singapore, Financial Market Integration in Singapore: The Narrow and the Broad Views, Occasional Paper No. 20, May 2000

Monetary Authority of Singapore, Singapore's Exchange Rate Policy, February 2001

Monetary Authority of Singapore, Notice 757 of 28 May 2004

Morgan Stanley, Global Network Management, Short-Selling Details - Equities, March 27,2003

Ngiam, K.J., Coping with the Asian Financial Crisis: The Singapore Experience, Visiting Researchers Series No. 8 (2000), Institute of Southeast Asian Studies, Singapore, March 2000

Ngiam, K.J., and L. Loh, Developing a Viable Corporate Bond Market: The Singapore Experience, Economics and Finance No. 2(2002), Institute of Southeast Asian Studies, Singapore, June 2002

Ong, L.H., 'Financial Leverage of Singapore Corporations, 1971-1997', Statistics Singapore Newsletter, $2^{\text {nd }}$ Quarter, 1998

Peebles, G., and P. Wilson, Economic Growth and Development in Singapore, London, Edward Elgar, 2002

Poitras, G., 'Short Sales Restrictions, Dilution, and the Pricing of Rights Issues on the Singapore Stock Exchange', Pacific-Basin Finance Journal, 10(2), 2002, 141-62

Rzepkowski, B., 'The Expectations of Hong Kong Dollar Devaluation and Their Determinants', Paris: CEPII Working Paper 2000-04, February 2000 
Shook Lin and Bok, 'MAS Liberalizes Singapore Dollar Policy', Legal Newsletter, 4 January 2001

Singapore Department of Statistics, Monthly Digest of Statistics, July 1998

Singapore Department of Statistics, Singapore's External Debt, Occasional Paper on Economic Statistics, December 1998

Singapore Department of Statistics, Singapore's External Debt: Definition and 1998 Assessment, Information Paper on Economic Statistics, January 2000

Starr, P., 'Singapore Props Up Currency', Australian Financial Review, 18 September 1985

Tan, A., 'MAS Chalks Up Handsome \$5b gain', Straits Times (Singapore), July 222004

Technical Committee, International Organization of Securities Commissions, Report on Transparency of Short Selling, June 2003

Teh, K.P., 'Monetary Policy in an Open Economy: Singapore', $17^{\text {th }}$ SEANZA (SouthEast Asia, New Zealand, Australia) Central Banking Course, Reserve Bank of Australia, Sydney

Textline Multiple Source Collection, 'Singapore's foreign exchange market is virtually back to normal', 20 September 1985 (from Factiva)

Thiam, H.N., 'Stock Market Linkages in South-East Asia', Asian Economic Journal, 16(4), 2002, 353-77

US Embassy, Singapore, 'Reforming Singapore's Financial Services Sector: A Background and Progress Report', May 1999

US Embassy, Singapore, 'Singapore - The Singapore Dollar Bond Market Develops', March 2001

Wong, S.J., 'Rising Bond Prices', Fundsupermart.com (Singapore), 10 December 2004

Yam, J., 'Defending Hong Kong's Monetary Stability', Speech at TDC Networking Luncheon, Singapore, 14 October 1998

Yam, J., 'Coping with Financial Turmoil', Inside Asia Lecture 1998, Sydney, 23 November 1998 
Figure 1: Singapore's Exchange Rates

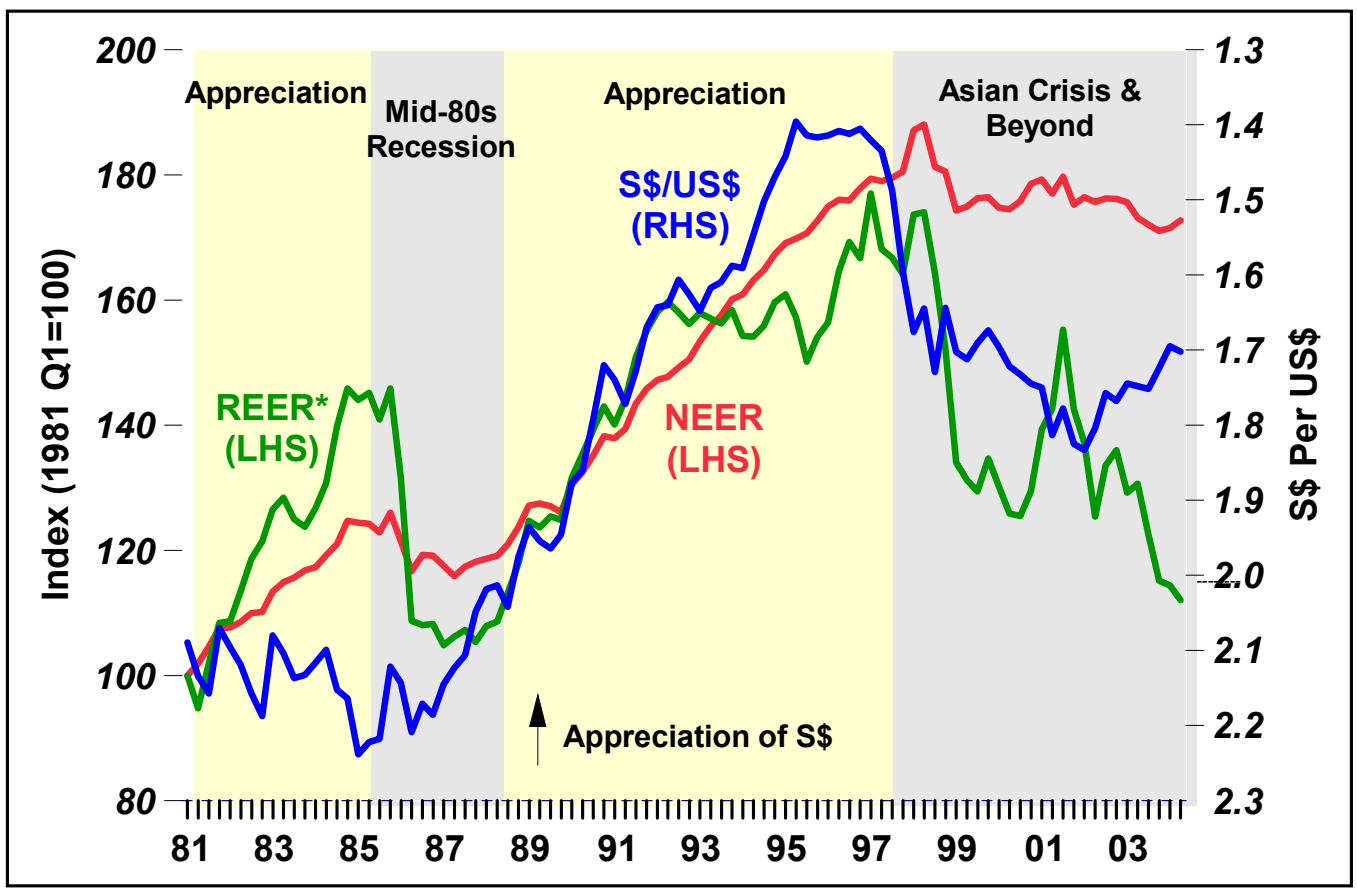

* Using export competitiveness weights and deflated by relative unit labour costs

Source: Monetary Authority of Singapore (2001), and kindly updated by the MAS 
Table 1 Key National Income Statistics, Singapore

\begin{tabular}{|c|c|c|c|c|c|c|}
\hline \multirow[t]{2}{*}{ Year } & $\begin{array}{c}\text { Gross National } \\
\text { Income } \\
\text { (GNI) } \\
\text { \$M }\end{array}$ & $\begin{array}{c}\text { Per Capita } \\
\text { GNI } \\
\$\end{array}$ & $\begin{array}{c}\text { Gross National } \\
\text { Saving } \\
\text { \$M }\end{array}$ & $\begin{array}{c}\text { Gross Capital } \\
\text { Formation } \\
\text { \$M }\end{array}$ & $\begin{array}{c}\text { Gross Domestic } \\
\text { Product } \\
\text { \$M }\end{array}$ & $\begin{array}{c}\text { Gross Fixed } \\
\text { Capital } \\
\text { Formation } \\
\$ M\end{array}$ \\
\hline & \multicolumn{4}{|c|}{ At Current Market Prices } & \multicolumn{2}{|c|}{ At 1995 Market Prices } \\
\hline 1993 & $94,604.0$ & 28,535 & $42,062.4$ & $35,258.2$ & $98,838.2$ & $32,439.3$ \\
\hline 1998 & $141,068.3$ & 35,968 & $75,416.8$ & $44,316.0$ & $138,345.0$ & $51,253.3$ \\
\hline 1999 & $142,617.3$ & 36,097 & $70,644.6$ & $44,739.5$ & $147,834.4$ & $48,717.8$ \\
\hline 2000 & $159,097.0$ & 39,599 & $73,984.6$ & $51,150.6$ & $162,162.3$ & $52,933.8$ \\
\hline 2001 & $155,472.3$ & 37,634 & $67,150.2$ & $38,296.3$ & $159,073.0$ & $50,549.3$ \\
\hline 2002 & $157,818.5$ & 37,834 & $67,238.5$ & $33,444.1$ & $162,493.2$ & $45,530.6$ \\
\hline \multirow[t]{2}{*}{2003} & $157,173.9$ & 37,555 & $70,351.3$ & $21,245.0$ & $164,265.9$ & $43,779.4$ \\
\hline & \multicolumn{6}{|c|}{ Percentage Change Over Previous Year } \\
\hline 1993 & 13.0 & 10.1 & 8.7 & 21.3 & 12.3 & 10.3 \\
\hline 1998 & -4.3 & -7.4 & -3.0 & -20.3 & -0.9 & -6.0 \\
\hline 1999 & 1.1 & 0.4 & -6.3 & 1.0 & 6.9 & -4.9 \\
\hline 2000 & 11.6 & 9.7 & 4.7 & 14.3 & 9.7 & 8.7 \\
\hline 2001 & -2.3 & -5.0 & -9.2 & -25.1 & -1.9 & -4.5 \\
\hline 2002 & 1.5 & 0.5 & 0.1 & -12.7 & 2.2 & -9.9 \\
\hline 2003 & -0.4 & -0.7 & 4.6 & -36.5 & 1.1 & -3.8 \\
\hline
\end{tabular}

Source: Yearbook of Statistics, 1994 (Singapore Department of Statistics) 
Table 2 Average Leverage Ratio During the 1970's, 1980's and 1990's

\begin{tabular}{llll} 
& $1970 \mathrm{~s}$ & $1980 \mathrm{~s}$ & $1990 \mathrm{~s}^{1}$ \\
\cline { 2 - 4 } & \multicolumn{2}{c}{ Average ratio during the period } \\
\hline$\underline{\text { Singapore }}$ & & & \\
Debt-to-Asset Ratio (DAR) & 0.33 & 0.36 & 0.31 \\
$\quad$ Short-term DAR & 0.24 & 0.24 & 0.21 \\
Long-term DAR & 0.09 & 0.12 & 0.10 \\
Short-to-Long-term Debt Ratio & 2.55 & 1.97 & 1.98 \\
Canada & & & \\
$\quad$ Debt-to-Asset Ratio (DAR) & 0.24 & 0.28 & 0.30 \\
Short-term DAR & 0.11 & 0.17 & 0.15 \\
Long-term DAR & 0.13 & 0.11 & 0.15 \\
Short-to-Long-term Debt Ratio & 0.86 & 1.53 & 1.04 \\
United States & & & \\
Debt-to-Asset Ratio (DAR) & 0.30 & 0.33 & 0.37 \\
Short-term DAR & 0.11 & 0.15 & 0.17 \\
Long-term DAR & 0.19 & 0.18 & 0.21 \\
Short-to-Long-term Debt Ratio & 0.59 & 0.85 & 0.80
\end{tabular}

For Singapore, data refer to period 1990 - 1997. For Canada, data refer to period 1990 - 1996. For the United States, data refer to period 1990 - 1994.

Source: Ong (1998)

TABLE 3 SINGAPORE'S EXTERNAL DEBT, END-95 TO END-98

\begin{tabular}{lrrrr} 
& & & & \$ million \\
\cline { 2 - 5 } Private Sector & End-95 & End-96 & End-97 & End-98P \\
\cline { 2 - 5 } Loans - BIS Banks & 9,801 & 12,341 & 16,490 & 14,734 \\
Loans - Non-BIS Banks & 6,921 & 7,390 & 11,161 & 9,274 \\
Loans - Other Non-Residents & 434 & 1,053 & 811 & 808 \\
Public Sector & 2,446 & 3,898 & 4,518 & 4,652 \\
\hline Total & 0 & 0 & 0 & 0 \\
\hline Previous Estimates & 9,801 & 12,341 & 16,490 & 14,734
\end{tabular}

Source: SDOS (2000) 
Table 4 Singapore Debt Sustainability Ratios, End-95 to End-98 (\%)

\begin{tabular}{crrrr}
\hline & End-95 & End-96 & End-97 & End-98P \\
\hline & & & & \\
& & & & \\
Debt/GNP & 8.1 & 9.3 & 11.2 & 10.0 \\
Debt/(Domestic) Exports & 10.0 & 11.9 & 15.3 & 13.9 \\
\hline
\end{tabular}

Source: SDOS (2000) 
TABLE 5 EXTERNAL DEBT SUSTAINABILITY RATIOS

OF SELECTED COUNTRIES

\begin{tabular}{lcccr}
\hline & End-93 & End-94 & End-95 & End-96 \\
\hline & External Debt/GNP & & \\
\hline Indonesia & 58.9 & 57.4 & 56.9 & 59.9 \\
Malaysia & 38.7 & 36.9 & 42.6 & 42.1 \\
Philippines & 64.1 & 59.3 & 51.5 & 47.3 \\
Thailand & 37.1 & 43.1 & 34.9 & 50.3 \\
\hline & External Debt/Exports & & \\
\hline Indonesia & 211.9 & 195.8 & 202.9 & 222.2 \\
Malaysia & 43.5 & 37.7 & 40.8 & 42.4 \\
Philippines & 187.0 & 160.6 & 121.8 & 97.6 \\
Thailand & 93.0 & 103.1 & 76.6 & 120.5 \\
\hline Sourc: & & & & \\
\hline
\end{tabular}

Source: World Bank, World Debt Tables.

Reproduced in SDOS (1998) 
Table 6 Overseas Loans of Local and Foreign-Owned Companies, End-97

\begin{tabular}{lrrrrrr} 
& \multicolumn{2}{c}{ Identified Bank Loans $^{1}$} & \multicolumn{2}{c}{ Non-Bank Loans } & \multicolumn{2}{c}{ Total } \\
& $\begin{array}{c}\text { Value } \\
\text { (\$ million) }\end{array}$ & $\begin{array}{c}\text { Share } \\
\text { (per cent) }\end{array}$ & $\begin{array}{c}\text { Value } \\
\text { (\$ million) }\end{array}$ & $\begin{array}{c}\text { Share } \\
\text { (per cent) }\end{array}$ & $\begin{array}{c}\text { Value } \\
\text { (\$ million) }\end{array}$ & $\begin{array}{l}\text { Share } \\
\text { (per cent) }\end{array}$ \\
\hline Local-Owned & 1,258 & 21 & 1,445 & 32 & 2,703 & 26 \\
Foreign-Owned & 4,754 & 79 & 3,073 & 68 & 7,827 & 74 \\
\hline Total & 6,012 & - & 4,518 & - & 10,530 \\
\hline 1 Bank loans that are identified in SDOS's surveys & & &
\end{tabular}

Source: SDOS (2000) 
Table 7 SECONDARY FORMS OF EXTERNAL DEBT, END-95 TO END-98

\begin{tabular}{|c|c|c|c|c|}
\hline & $\begin{array}{l}\text { End- } \\
95^{1}\end{array}$ & $\begin{array}{l}\text { End- } \\
96\end{array}$ & $\begin{array}{l}\text { End- } \\
97\end{array}$ & $\frac{\frac{\$}{\text { million }}}{\frac{\text { End- }}{\underline{98 \mathrm{P}}}}$ \\
\hline Debt Securities & 1,952 & 2,419 & 3,585 & 3,662 \\
\hline FDI Non-Equity Capital - Net Liability & 5,194 & 5,687 & 7,808 & 7,792 \\
\hline Loans & & 4,074 & 5,437 & 5,752 \\
\hline Trade Credits - Liabilities & 9,852 & 6,830 & 7,431 & 6,825 \\
\hline Trade Credits - Assets & 4,658 & 5,217 & 5,060 & 4,785 \\
\hline Non-FDI Trade Credits - Net Asset & 3,267 & 6,238 & 8,092 & 7,072 \\
\hline Assets & 16,662 & 17,632 & 21,148 & 19,639 \\
\hline Liabilities & 13,395 & 11,394 & 13,056 & 12,567 \\
\hline
\end{tabular}

1 Data for 1995 has been revised

Source: SDOS (2000)

TABLE 8 NET EXTERNAL POSITION - LOANS AND DEBT SECURITIES, END-96 TO END-97

\$ million

\begin{tabular}{lrl} 
& End-96 & End-97 \\
\hline Debt Securities & 6,303 & 7,454 \\
Assets & 8,722 & 11,039 \\
Liabilities & 2,419 & 3,585 \\
\hline Loans - Other Non-Residents & 4,804 & 6,846 \\
Assets & 8,702 & 11,364 \\
Liabilities & 3,898 & 4,518 \\
\hline \multicolumn{2}{c}{ Loans - $\quad 3,518$} & 3,944 \\
$\quad$ FDI & 7,592 & 9,381 \\
Assets (Outward FDI) & 4,074 & 5,437 \\
Liabilities (Inward FDI) &
\end{tabular}

Source: SDOS (2000) 
Figure 2: S\$ and US\$ bond yields

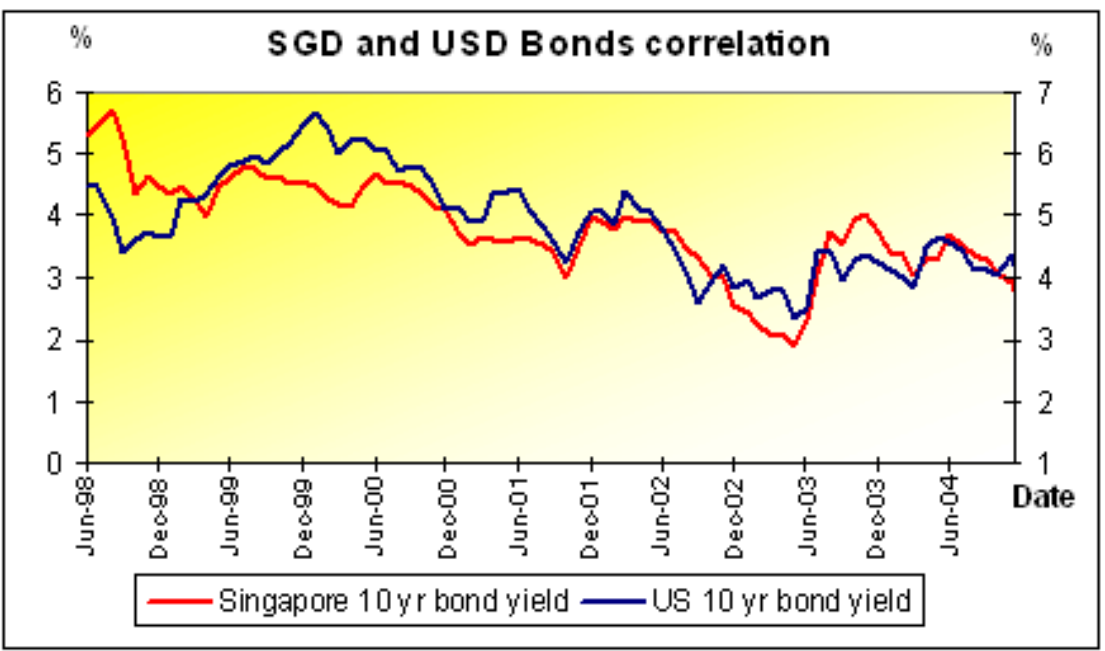

Source: Bloomberg (quoted in Wong, op. cit.: the left column measures the Singapore bond yield)

Figure 3: US\$ and S\$ bond yields (cont.)

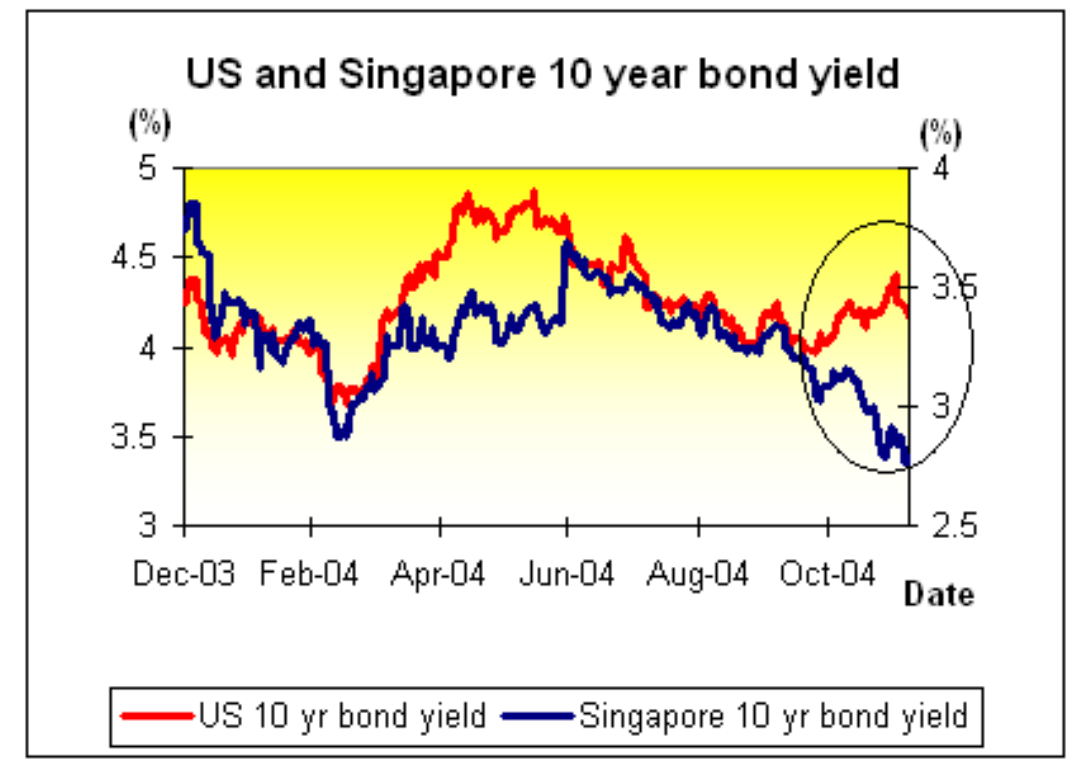

Source: Bloomberg (quoted in Wong, op. cit: : the left column measures the US bond yield) 